\title{
Steganografi Citra Menggunakan Metode Least Significant Bit (LSB) Dan Linear Congruential Generator (LCG)
}

\author{
Andre Hernandes ${ }^{* 1}$, Hartini ${ }^{2}$, Dewi Sartika ${ }^{3}$ \\ ${ }^{1,3}$ Program Studi Informatika Universitas Indo Global Mandiri, Palembang \\ ${ }^{2}$ Program Studi Teknik komputer AMIK Sigma Palembang \\ e-mail: ${ }^{* 1}$ andrehernandes4@gmail.com, ${ }^{2}$ arpi.hatini.my@gmail.com, \\ ${ }^{3}$ dewi.sartika@uigm.ac.id
}

\begin{abstract}
Abstrak
Steganografi merupakan sebuah cara yang digunakan untuk menyembunyi-kan pesan rahasia dari orang yang tidak berhak mengetahuinya. Pada penelitian ini penulis menggunakan salah satu metode steganografi yaitu metode least significant bit (LSB) untuk menyisipkan bitbit pesan rahasia berupa teks kedalam citra digital RGB berekstensi file bitmap, dengan cara menggabungkan metode LSB dan linear congruential generator (LCG) untuk membangkitkan bilangan acak dari posisi pixel yang akan disisipkan pesan rahasia. Hasil dari penelitian ini penulis berhasil membangun aplikasi steganografi dengan bahasa pemrograman java dan menguji kualitas stego image yang menghasilkan nilai rata-rata Peak Signal to Noise Ratio (PSNR) yang mencapai 51 dB. Dari penilaian ini, disimpulkan bahwa stego image yang dihasilkan dalam kualitas baik dan tidak mengalami perubahan yang signifikan.
\end{abstract}

Kata kunci-LCG, LSB, PSNR, Steganografi

\begin{abstract}
Steganography is a method used to hide secret messages from people who are not entitled to know it. In this study the author uses one of the steganography methods, the least significant bit method (LSB) to insert bits of secret message in the form of text into digital images RGB bitmap file extension, by combining the LSB method and linear congruential generator (LCG) to generate random numbers from the position of the pixel that will be inserted a secret message. The results of this study the authors managed to build steganography applications with the Java programming language and test the quality of stego image that produces an average value Peak Signal to Noise Ratio (PSNR) that reach 51 dB. From this assessment, it was concluded that stego image produced in good quality and did not experience significant changes.
\end{abstract}

Keywords—LCG, LSB, PSNR, Steganography

\section{PENDAHULUAN}

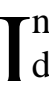
nformasi merupakan bagian yang sangat penting sekarang ini. Seiring dengan kemudahan dalam mendapatkan informasi sehingga ini menjadi ancaman terhadap keamanan informasi yang dibutuhkan semakin besar, terutama untuk informasi yang dirahasiakan. Permasalahan tersebut dapat diatasi dengan teknik penyembunyian data. Teknik penyembunyian data yang terkenal adalah steganografi. Kata steganografi berasal dari bahasa Yunani, yaitu dari kata Stegos yang berarti tersembunyi (covered) dan Graphein yang berarti tulisan (writing). Steganografi di dunia modern biasanya mengacu pada informasi atau suatu arsip yang telah disembunyikan ke dalam suatu arsip citra digital, audio, atau video. Steganografi adalah suatu 
teknik untuk menyembunyikan informasi yang bersifat pribadi dengan sesuatu yang hasilnya akan tampak seperti informasi normal lainnya [1].

Teknik steganografi ini telah banyak digunakan dalam strategi peperangan dan pengiriman sandi rahasia sejak jaman Yunani. Penguasa Yunani dalam mengirimkan pesan rahasia menggunakan kepala budak atau prajurit sebagai media. Dalam hal ini, rambut sudah dibotaki, lalu pesan ditulis pada kulit kepala budak. Ketika rambut budak tumbuh, budak tersebut diutus untuk membawa pesan rahasia dikepalanya. Cerita lain tentang steganografi datang juga dari sejarawan Yunani, Herodutus, yaitu dengan cara menulis pesan pada kayu yang ditutup dengan lilin. Demeratus, seorang Yunani yang akan mengabarkan berita kepada Sparta bahwa Xerxes bermaksud menyerbu Yunani. Agar tidak diketahui pihak Xerxes, Demeratus menulis pesan dengan cara mengisi tabung kayu dengan lilin dan menulis pesan dengan mengukirnya pada bagian bawah kayu, lalu papan kayu tersebut dimasukkan ke dalam tabung kayu, kemudian tabung kayu ditutup dengan lilin [2].

Media yang digunakan umumnya merupakan suatu media yang berbeda dengan media pembawa informasi rahasia. Dalam penelitian ini media penampung yang digunakan adalah citra digital image dan media yang disembunyikan data berupa file teks, dimana disinilah fungsi dari teknik steganografi yaitu sebagai teknik penyamaran menggunakan media lain yang berbeda sehingga informasi rahasia dalam media awal tidak terlihat secara jelas. Steganografi biasanya sering disalah artikan dengan kriptografi karenanya keduanya sama-sama bertujuan untuk melindungi informasi yang berharga. Perbedaan yang mendasar antara keduanya yaitu steganografi berhubungan dengan informasi tersembunyi sehingga tampak seperti tidak ada informasi tersembunyi sama sekali. Jika seseorang mengamati obyek yang menyimpan informasi tersembunyi tersebut, maka dia tidak akan menyangka bahwa terdapat pesan rahasia dalam obyek tersebut, dan karenanya dia tidak akan berusaha memecahkan informasi dari obyek tersebut sedangkan kriptografi informasi tampak jelas sehingga seseorang tertarik untuk memecahkan informasi yang tersembunyi.

Sebagai pertimbangan dalam penelitian ini akan dicantumkan penelitian terdahulu yang dilakukan oleh Haikal Nando Winata dan Raja Nasrul Fuad dengan judul konsep penyandian file jpeg dengan menggunakan metode LSB dapat ditarik kesimpulan bahwa aplikasi steganografi dengan implementasi metode LSB dapat digunakan dengan baik dalam melakukan penyembunyian pesan (teks) [3]. Penelitian serupa juga pernah dilakukan oleh Endang Ratnawati Djuwitaningrum dan Melisa Apriyani dengan judul Text Message Steganograph Using Least Significant Bit Method and Linear Congruential Generator Algorithm telah di presentasikan penyisipan pesan teks ke dalam sebuah citra warna 24 bit menggunakan metode LSB 2 bit dan algoritma LCG, dan dalam mengimplementasikan algoritma LCG untuk membangkitkan bilangan acak semu, nilai konstanta m sebaiknya tidak sama dengan jumlah pixel cover image, sehingga nilai ini yang juga merupakan nilai stego key akan lebih tahan terhadap serangan brute force attack [4].

Semakin pentingnya nilai dari sebuah informasi, maka semakin berkembang pula metodemetode yang dapat digunakan untuk melakukan steganografi, mulai dari teknik transformation, redundant pattern encoding, spread spectrum method dan least significant bit (LSB). Pada penelitian ini Least significant bit dipilih sebagai metode yang akan digunakan, hal ini dikarenakan metode LSB merupakan metode yang paling sederhana dengan menyisipkan informasi ke dalam bit rendah atau paling kanan pada data pixel yang menyusun file tersebut dan format yang mempunyai nilai bits redundancy tinggi. Bit redudancy adalah bit yang dapat dirubah tanpa merubah banyak karakteristik file secara keseluruhan, sehingga meminimalisir perubahan yang signifikan pada pixel file citra yang telah disisipkan informasi rahasia. Penggunaan LSB tidaklah cukup untuk menyembunyikan informasi rahasia ini dikarenakan banyaknya tools open source yang dapat mengekstrak pesan dan informasi yang disembunyikan 
pada media citra digital. Sehingga pada penelitian ini untuk menambah keamanan dari data yang akan disisipkan pada citra maka ditambah dengan menggunakan metode pembangkit bilangan acak Pseudorandom Number Generator (PRNG) salah satu metode yang digunakan adalah Linear Congruential Generator (LCG) untuk membangkitkan bilangan acak sebagai penentu posisi pixel yang akan disisipkan pesan rahasia. Berdasarkan permasalahan diatas penulis merumuskan judul "Steganografi Citra Menggunakan Metode Least Significant Bit (LSB) dan Linear Congruential Generator (LCG)".

\section{METODE PENELITIAN}

\subsection{Tahapan Penelitian}

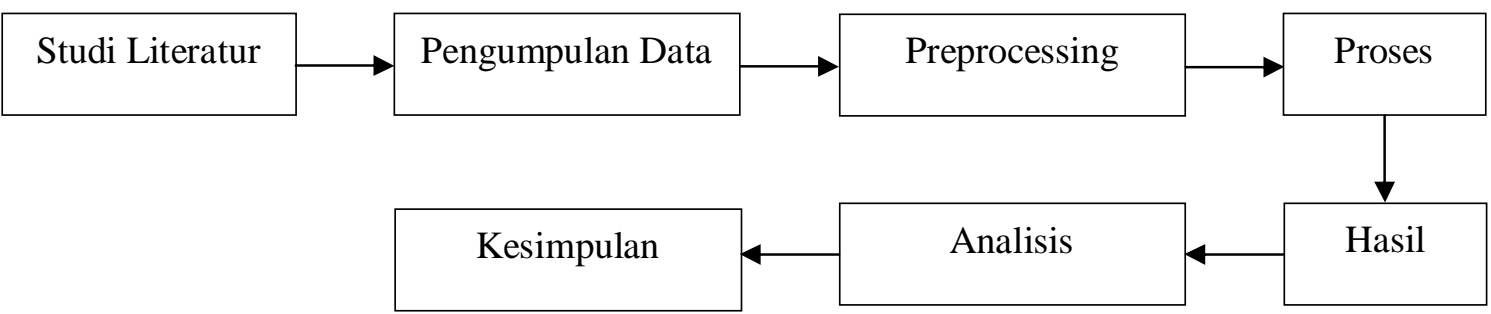

Gambar 1. Tahapan Penelitian

\subsubsection{Pengumpulan Data}

Berikut teknik pengumpulan data yang dilakukan didalam penelitian ini:

a. Studi literatur

Tahap pengumpulan data berdasarkan sumber-sumber literatur seperti jurnal, buku-buku, artikel, paper, makalah yang berhubungan dengan pembuatan aplikasi steganografi citra.

b. Data Sekunder

Data yang digunakan dalam penelitian ini menggunakan data sekunder berupa 4 buah citra RGB (Red, Green, Blue) 24 bit berformat .*bmp (bitmap) dengan 3 ukuran citra yang digunakan yaitu $100 \times 100$ pixel, $500 \times 500$ pixel dan $1000 \times 1000$ pixel. Pengumpulan data sekunder menggunakan instrumen penelitian internet, jadi data citra yang digunakan ini didapatkan dari web di internet melalui mesin pencarian google dengan kata kunci "24 bit bitmap image".

Tabel 1. Citra Bitmap 24 bit RGB

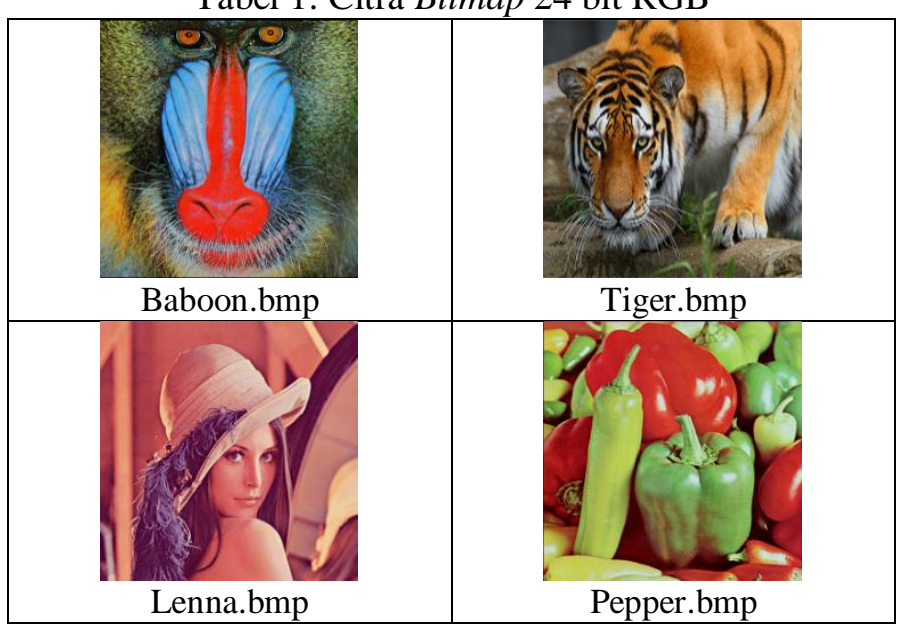




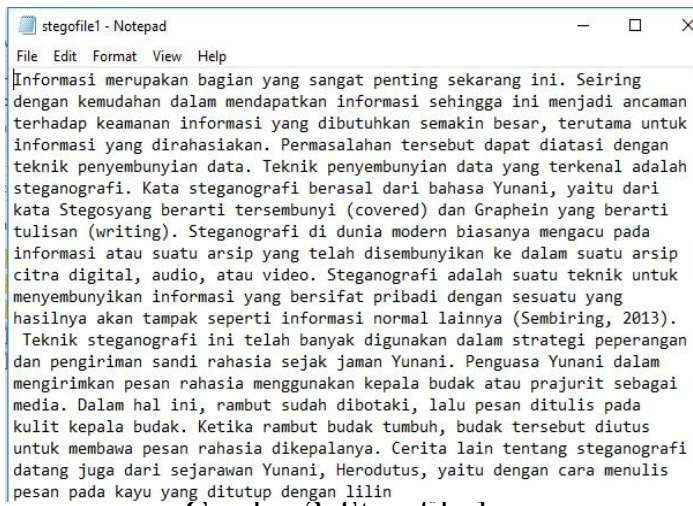

\subsubsection{Metode Pengembangan Aplikasi}

Metode pengembangan perangkat lunak yang di pakai adalah RUP (Rational Unified Process). (Rosa A.S dan M.shalahuddin, 2015) [5] Rational Unified Process atau dikenal juga dengan proses iterative dan Incremental merupakan sebuah proses pengembangan perangkat lunak yang dilakukan secara iterative (berulang) dan incremental (bertahan dengan progress menaik). RUP memiliki 4 (empat) buah tahap atau fase yang dapat dilakukan pula secara iteratif yaitu inception, elaboration, construction, transition.

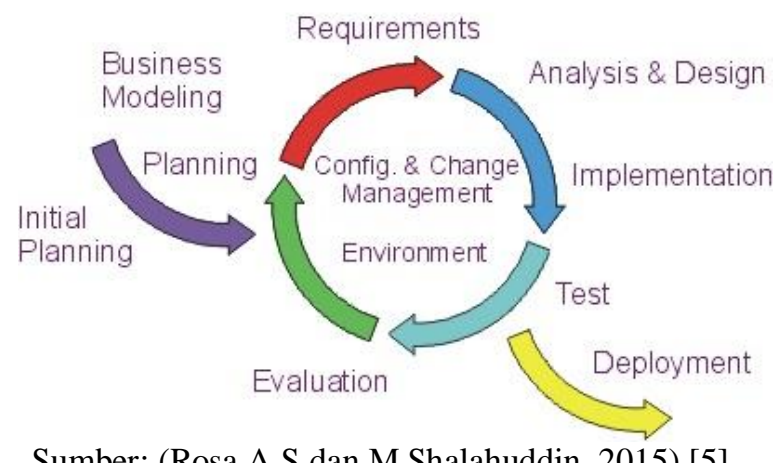

Sumber: (Rosa A.S dan M.Shalahuddin, 2015) [5]

Gambar 4. Metode RUP

\subsection{Deskripsi Umum Aplikasi \\ Preprocessing}

Proses penyisipan pada penelitian ini dimulai dengan prepocessing citra digunakan untuk menormalisasi citra (resize) menjadi ukuran yang telah ditentukan pada batasan masalah penelitian menjadi 100 x 100 pixel, 500 x 500 pixel dan 1000 x 1000 pixel dengan menggunakan tools Paint pada dekstop windows.

\section{Alur Proses}

Alur proses keseluruhan aplikasi steganografi metode LSB dan LCG dimulai dengan cara memasukkan citra penampung (cover image) dan memasukkan pesan rahasia yang akan disisipkan. Proses dimulai dengan mengacak dengan metode LCG untuk menentukan posisi pixel yang akan disisipkan pesan rahasia yang kemudian akan disisipkan dengan metode LSB pada tiap 1 bit RGB terakhir pixel yang telah ditentukan. Hasil citra yang disisipkan pesan rahasia ini sebut dengan stego image. 


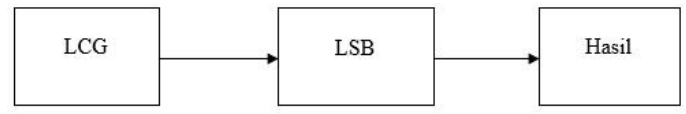

Gambar 5. Alur Proses

\subsection{Metode Linear Congruential Generator}

Algoritma Linear Congruential Generator (LCG) [6], digunakan untuk menghasilkan bilangan acak semu, yang diberikan dalam bentuk persamaan sebagai berikut:

Keterangan:

$$
X_{i}=\left(a X_{i-1}+b\right) \bmod m
$$

$$
\begin{array}{ll}
\mathrm{Xi}-1 & =\text { bilangan acak sebelumnya } \\
\mathrm{Xi} & =\text { bilangan acak ke- } \mathrm{i} \\
\mathrm{a} & =\text { konstanta pengali } \\
\mathrm{b} & =\text { konstanta kenaikan (penambah) } \\
\mathrm{m} & =\text { konstanta modulus }
\end{array}
$$

Persamaan 1 memiliki nilai awal X0 sebagai kunci pembangkit atau sering juga disebut umpan (seed). X0 merupakan bilangan bulat lebih besar atau sama dengan nol dan lebih kecil dari $\mathrm{m}$. LCG mempunyai periode tidak lebih besar dari $\mathrm{m}$ dan akan mempunyai periode penuh jika memenuhi syarat sebagai berikut [2]:

1. b relatif prima terhadap $m$.

2. (a - 1) dapat dibagi dengan semua faktor prima dari $m$.

3. (a - 1) adalah kelipatan 4 jika m adalah kelipatan 4.

4. $\mathrm{m}>\operatorname{maks}(\mathrm{a}, \mathrm{b}, \mathrm{X} 0)$.

5. $a>0, b>0$

Algoritma LCG mempunyai periode yang tidak lebih besar dari modulus (m), modulus ini merupakan ambang batas maksimum dalam pengacakan bilangan. Semakin besar ukuran citra yang akan disisipi pesan, semakin besar pula periodik LCG yang dapat dibangkitkan, sehingga semakin banyak pula pesan yang bisa disisipkan.

Tujuan LCG pada citra adalah untuk mengacak posisi penyisipan pada pixel yang akan disisipkan pesan rahasia (Secret Message). Citra yang dimasukkan akan terlebih dahulu diubah kedalam matriks, kemudian menghitung jumlah pixel yang dibutuhkan sesuai dengan banyaknya pesan rahasia yang akan disisipkan. Pengacakan menggunakan metode LCG (Linear Congruential Generator) untuk menentukan posisi pixel dalam melakukan proses penyisipan pesan. Berikut Pseudocode LCG untuk membangkitkan bilangan acak:

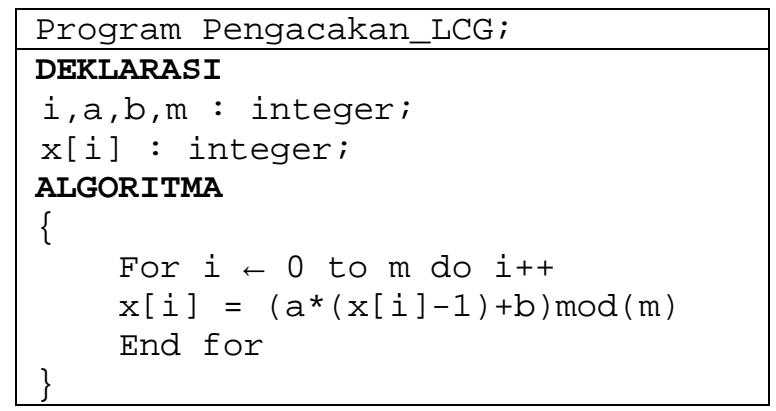

Pada ilustrasi ini ditentukan bahwa nilai konstanta $m=36, a=13, X_{0}=1$ dan $b=35$ yang memenuhi syarat periode penuh. Dengan mensubtitusi nilai konstanta $\mathrm{m}=$ jumlah seluruh pixel, konstanta a dan $\mathrm{b}$ dihitung agar dapat menghasilkan bilangan acak sebanyak modulus (m). 
Setelah itu dimasukkan kedalam persamaan $X_{i}=\left(13 x_{i-1}+35\right) \bmod 36$ maka akan didapat angka acak yang dapat terlihat pada Tabel 2:

Tabel 2. Perhitungan Angka Semu Acak

\begin{tabular}{|c|c|}
\hline $\mathbf{i}$ & $\mathbf{X}_{\mathbf{i}}$ \\
\hline $\mathbf{0}$ & 1 \\
\hline $\mathbf{1}$ & 12 \\
\hline $\mathbf{2}$ & 11 \\
\hline $\mathbf{3}$ & 34 \\
\hline $\mathbf{4}$ & 9 \\
\hline $\mathbf{5}$ & 8 \\
\hline $\mathbf{6}$ & 31 \\
\hline $\mathbf{7}$ & 6 \\
\hline $\mathbf{8}$ & 5 \\
\hline $\mathbf{9}$ & 28 \\
\hline $\mathbf{1 0}$ & 3 \\
\hline $\mathbf{1 1}$ & 2 \\
\hline
\end{tabular}

\begin{tabular}{|c|c|}
\hline $\mathbf{1 2}$ & 25 \\
\hline $\mathbf{1 3}$ & 0 \\
\hline $\mathbf{1 4}$ & 35 \\
\hline $\mathbf{1 5}$ & 22 \\
\hline $\mathbf{1 6}$ & 33 \\
\hline $\mathbf{1 7}$ & 32 \\
\hline $\mathbf{1 8}$ & 19 \\
\hline $\mathbf{1 9}$ & 30 \\
\hline $\mathbf{2 0}$ & 29 \\
\hline $\mathbf{2 1}$ & 16 \\
\hline $\mathbf{2 2}$ & 27 \\
\hline $\mathbf{2 3}$ & 26 \\
\hline $\mathbf{2 4}$ & 13 \\
\hline
\end{tabular}

\begin{tabular}{|c|c|}
\hline $\mathbf{2 5}$ & 24 \\
\hline $\mathbf{2 6}$ & 23 \\
\hline $\mathbf{2 7}$ & 10 \\
\hline $\mathbf{2 8}$ & 21 \\
\hline $\mathbf{2 9}$ & 20 \\
\hline $\mathbf{3 0}$ & 7 \\
\hline $\mathbf{3 1}$ & 18 \\
\hline $\mathbf{3 2}$ & 17 \\
\hline $\mathbf{3 3}$ & 4 \\
\hline $\mathbf{3 4}$ & 15 \\
\hline $\mathbf{3 5}$ & 14 \\
\hline $\mathbf{3 6}$ & 1 \\
\hline
\end{tabular}

Dari Tabel 2 perhitungan angka semu acak yang dihasilkan, bilangan acak berulang lagi pada $\mathrm{i}=36$. Sehingga modulus $(\mathrm{m})$ sebagai batas maksimum dalam pengacakan angka semu acak.

\subsection{Metode Least Significant Bit}

Salah satu metode untuk menyembunyikan informasi adalah Least Significant Bit (LSB) pada data citra. Metode penyisipan ini didasarkan pada kenyataan bahwa bit paling signifikan dalam foto dapat dianggap noise acak, dan akibatnya seseorang menjadi tidak responsif terhadap perubahan pada gambar. Least significant bit (LSB) adalah jenis yang paling umum digunakan dalam skema penyisipan yang digunakan saat ini dalam steganografi digital. Metode ini mungkin adalah cara termudah menyembunyikan informasi dalam gambar dan namun sangat efektif. Menyisip pesan rahasia yang tersembunyi dengan mengubah sedikit yang signifikan dalam lapisan tertentu dari file gambar (Ahmed Laskar and Hemachandran, 2012).

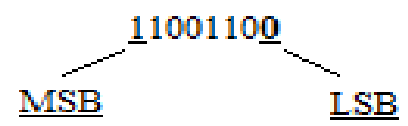

\section{Gambar 6. Posisi MSB dan LSB}

Setelah proses LCG atau pengacakan selanjutnya proses penyisipan pesan rahasia (Secret Message) menggunakan metode LSB (Least Significant Bit) yang menyisipkan pesan rahasia kedalam 1 bit terakhir tiap-tiap pixel RGB. Bit-bit dari pesan rahasia terlebih dahulu diubah kedalam bentuk kode ASCII atau biner dan matriks pixel yang telah ditentukan juga diubah kedalam bentuk kode ASCII atau biner, barulah proses penyisipan dimulai dengan menyisipkan bit-bit pesan rahasia kedalam 1 bit terakhir tiap pixel RGB yang telah ditentukan.

Berikut algoritma LSB untuk proses penyisipan:

1. Inisialisasi awal: proses penyisipan hanya menyisipkan pesan ke dalam tiap 1 bit terakhir (LSB) pada citra RGB, ukuran citra >= Pesan yang disisipkan

Output: Stego image

2. Masukkan Citra RGB

3. Ubah Citra RGB menjadi Matriks kemudian ubah Matriks ke biner

4. Masukkan Pesan teks $<=$ Citra RGB

5. Ubah Pesan teks menjadi biner 
6. Sisipkan setiap 1 bit pesan teks untuk dimasukkan kedalam 1 bit terakhir pada setiap nilai citra RGB

7. Mentransformasikan nilai biner hasil proses penyisipan kedalam nilai citra RGB

8. Simpan citra yang sudah disisipkan pesan menjadi Stego image

\subsection{Flowchart Penyisipan}
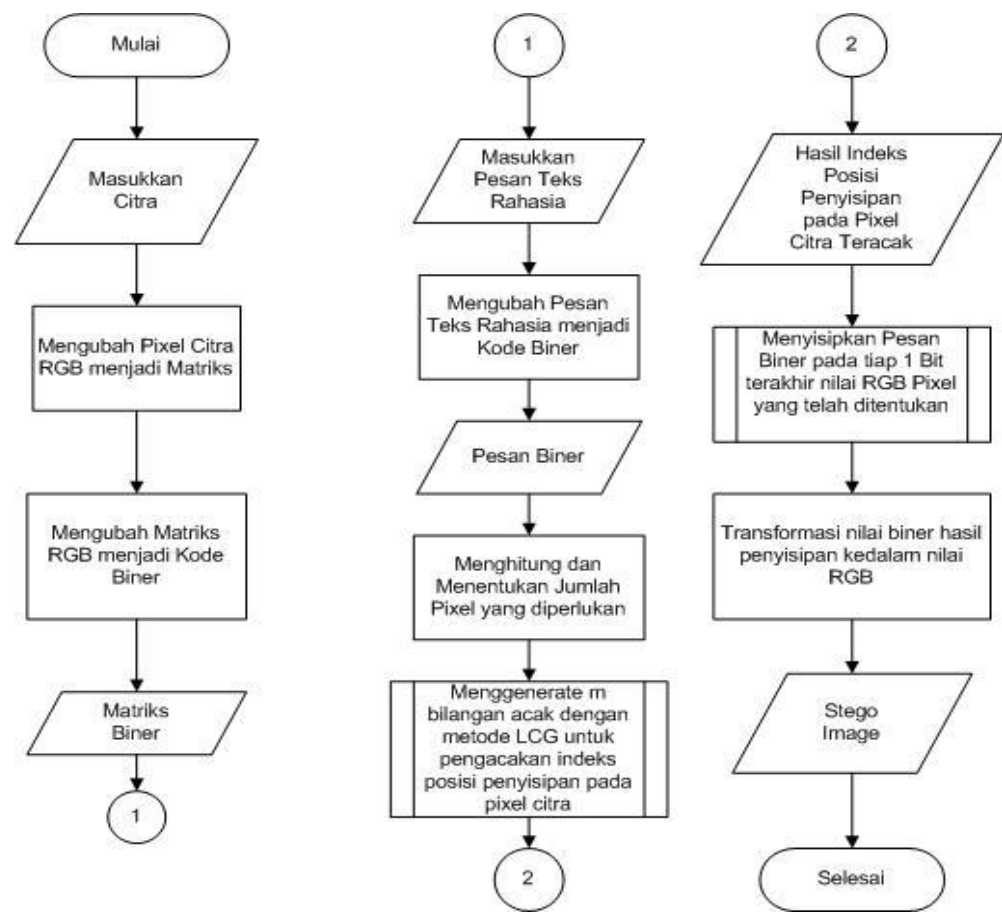

Gambar 7. Flowchart Penyisipan

\subsection{Flowchart Ekstraksi}
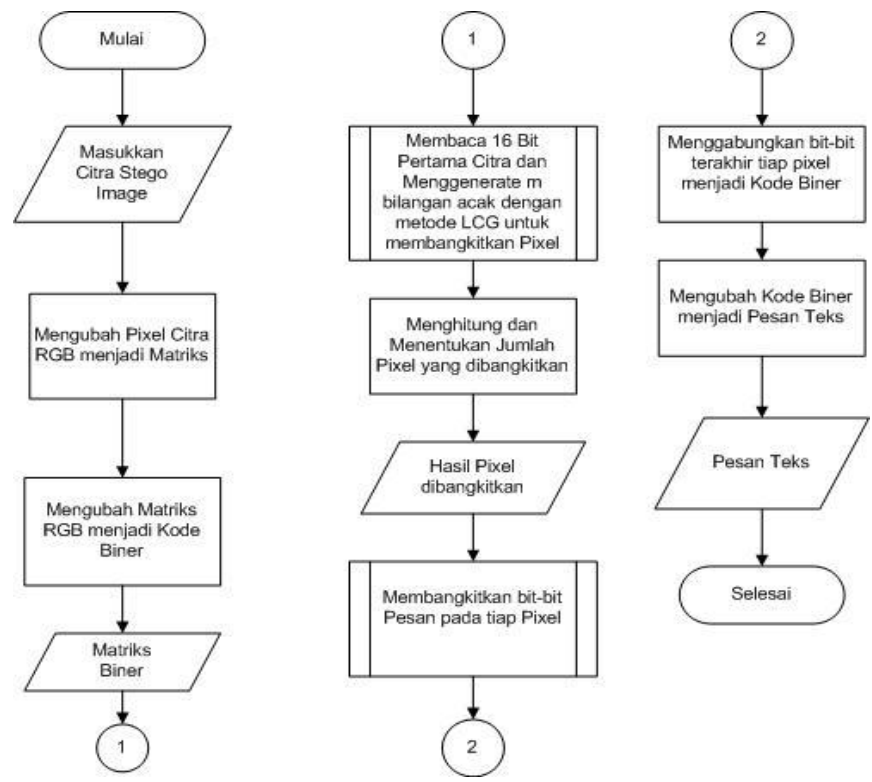

Gambar 8. Flowchart Ekstraksi 


\subsection{Implementasi}

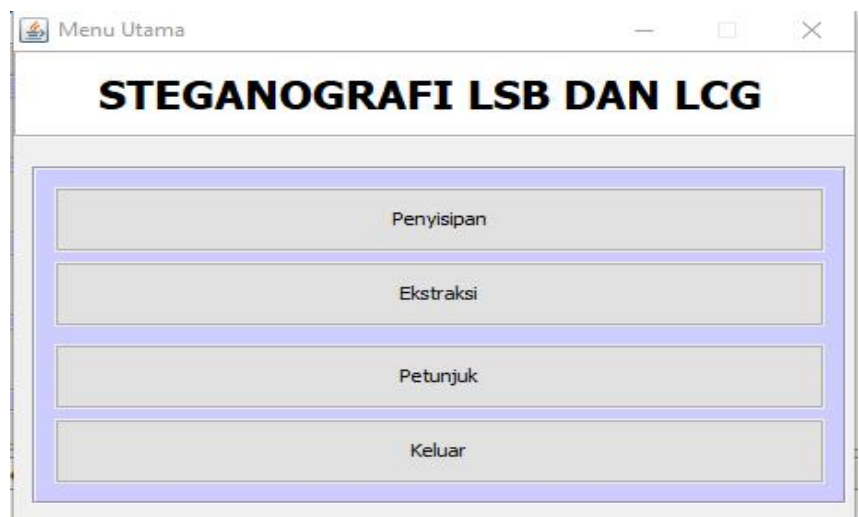

Gambar 9. Implementasi Menu Utama

Tampilan Menu Utama terdiri dari 4 buah tombol Penyisipan, Ekstraksi, Petunjuk dan Keluar

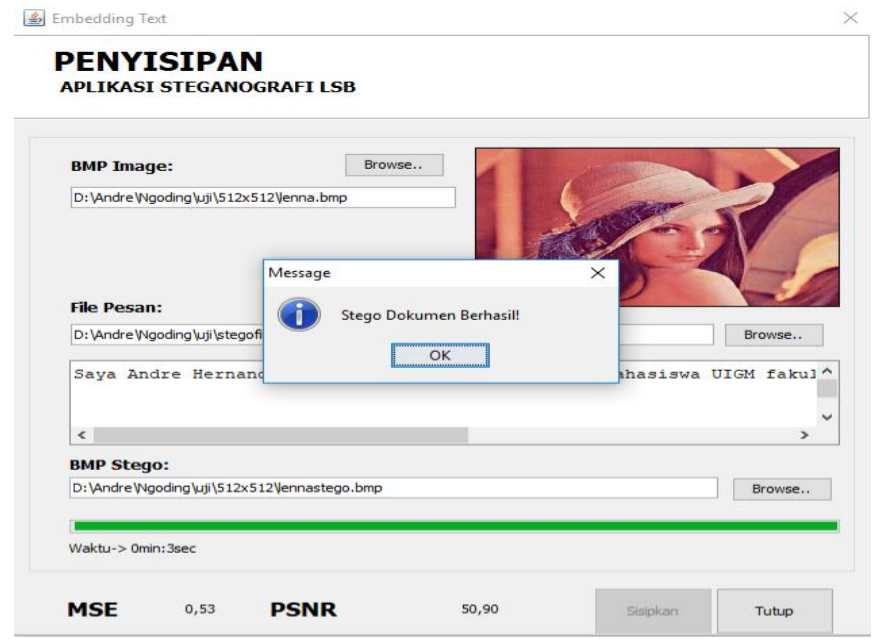

Gambar 10. Implementasi Menu Penyisipan

Pada menu penyisipan masukkan citra penampung berformat .bmp,pesan teksberformat .txt yang akan disembunyikan dan lokasi penyimpanan file hasil stego image kemudian pilih sisipkan. Setelah diproses akan tampil lama waktu proses penyisipan, MSE dan PSNR.

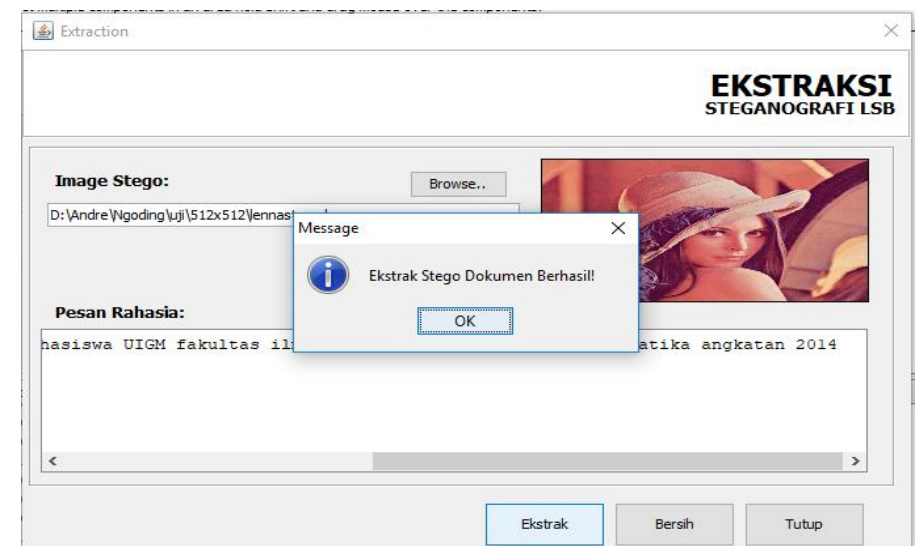

Gambar 11. Implementasi Menu Ekstraksi 
Pada menu ekstraksi masukkan stego image berformat .bmp yang akan diekstraksi kemudian pilih ekstrak. Setelah itu akan tampil pesan rahasia yang tersembunyi didalam stego image.

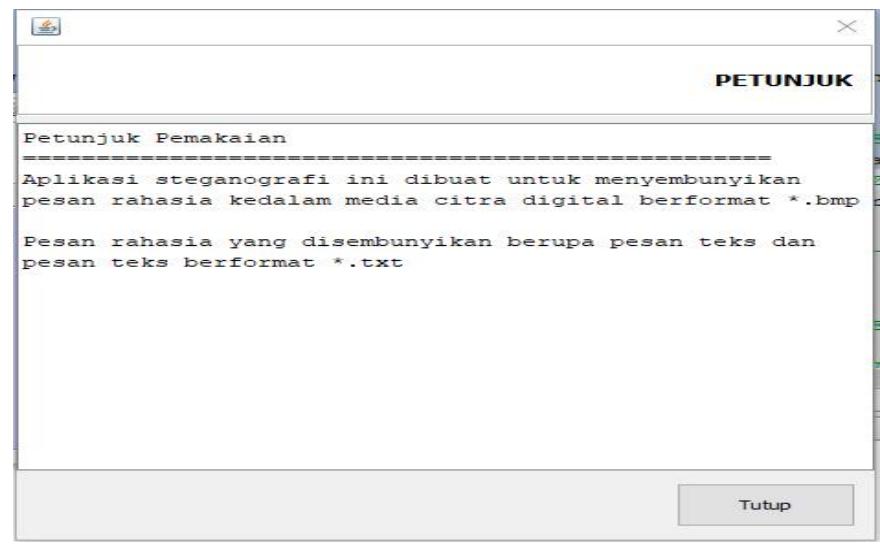

Gambar 12. Implementasi Menu Petunjuk

Pada menu petunjuk berisi petunjuk penggunaan aplikasi.

\section{HASIL DAN PEMBAHASAN}

Citra yang telah disisipkan sebanyak 24 citra bitmap dengan ukuran 100x100, 500x500,1000x1000 pixel dan berhasil menyisipkan pesan teks berformat txt dengan nama file stegofile1.txt dan stegofile2.txt. Pengujian dilakukan dengan membandingkan ukuran file, pengujian recovery untuk mengukur pesan yang disembunyikan harus dapat diungkapkan kembali dan menghasilkan pesan yang sama dengan yang disisipkan dan pengujian PSNR untuk membandingkan kualitas citra sebelum dan sesudah disisipkan pesan apakah terdapat perubahan (noise) yang signifikan pada pixel citra setelah dilakukan proses penyisipan bit-bit pesan.

\subsection{Pengujian}

Pengujian yang penulis lakukan yaitu pengujian sistem menggunakan Block-Box testing, pengujian perbandingan ukuran file, pengujian recovery dan pengujian PSNR.

\subsubsection{Pengujian Sistem}

Black-Box Testing yaitu menguji perangkat lunak dari segi spesifikasi fungsional tanpa menguji desain dan kode program. Pengujian dimaksudkan untuk mengetahui apakah fungsifungsi, masukan, dan keluaran dari perangkat lunak sesuai dengan spesifikasi yang dibutuhkan.

\subsubsection{Pengujian Perbandingan Ukuran File}

Pengujian perbandingan antara ukuran file cover image dan stego image dapat dilihat pada Tabel 3 .

Tabel 3. Perbandingan Ukuran File

\begin{tabular}{|l|l|l|l|l|}
\hline No. & \multicolumn{1}{|c|}{ Cover Image } & \multicolumn{1}{|c|}{ Pesan Rahasia } & \multicolumn{1}{|c|}{$\begin{array}{c}\text { Ukuran File Cover } \\
\text { Image }\end{array}$} & $\begin{array}{c}\text { Ukuran File Stego } \\
\text { Image }\end{array}$ \\
\hline 1. & Baboon100.bmp & Stegofile1.txt & 30,054 byte & 30,054 byte \\
\hline 2. & Baboon500.bmp & Stegofile1.txt & 750,054 byte & 750,054 byte \\
\hline 3. & Baboon1000.bmp & Stegofile1.txt & $3,000,054$ byte & $3,000,054$ byte \\
\hline 4. & Lenna100.bmp & Stegofile1.txt & 30,054 byte & 30,054 byte \\
\hline 5. & Lenna500.bmp & Stegofile1.txt & 750,054 byte & 750,054 byte \\
\hline
\end{tabular}




\begin{tabular}{|l|l|l|l|l|}
\hline 6. & Lenna1000.bmp & Stegofile1.txt & $3,000,054$ byte & $3,000,054$ byte \\
\hline 7. & Pepper100.bmp & Stegofile1.txt & 30,054 byte & 30,054 byte \\
\hline 8. & Pepper500.bmp & Stegofile1.txt & 750,054 byte & 750,054 byte \\
\hline 9. & Pepper1000.bmp & Stegofile1.txt & $3,000,054$ byte & $3,000,054$ byte \\
\hline 10. & Tiger100.bmp & Stegofile1.txt & 30,054 byte & 30,054 byte \\
\hline 11. & Tiger500.bmp & Stegofile1.txt & 750,054 byte & 750,054 byte \\
\hline 12. & Tiger1000.bmp & Stegofile1.txt & $3,000,054$ byte & $3,000,054$ byte \\
\hline 13. & Baboon100.bmp & Stegofile2.txt & 30,054 byte & 30,054 byte \\
\hline 14. & Baboon500.bmp & Stegofile2.txt & 750,054 byte & 750,054 byte \\
\hline 15. & Baboon1000.bmp & Stegofile2.txt & $3,000,054$ byte & $3,000,054$ byte \\
\hline 16. & Lenna100.bmp & Stegofile2.txt & 30,054 byte & 30,054 byte \\
\hline 17. & Lenna500.bmp & Stegofile2.txt & 750,054 byte & 750,054 byte \\
\hline 18. & Lenna1000.bmp & Stegofile2.txt & $3,000,054$ byte & $3,000,054$ byte \\
\hline 19. & Pepper100.bmp & Stegofile2.txt & 30,054 byte & 30,054 byte \\
\hline 20. & Pepper500.bmp & Stegofile2.txt & 750,054 byte & 750,054 byte \\
\hline 21. & Pepper1000.bmp & Stegofile2.txt & $3,000,054$ byte & $3,000,054$ byte \\
\hline 22. & Tiger100.bmp & Stegofile2.txt & 30,054 byte & 30,054 byte \\
\hline 23. & Tiger500.bmp & Stegofile2.txt & 750,054 byte & 750,054 byte \\
\hline 24. & Tiger1000.bmp & Stegofile2.txt & $3,000,054$ byte & $3,000,054$ byte \\
\hline
\end{tabular}

Berdasarkan Tabel 3 diperoleh hasil perbandingan antara file cover image dan file stego image (file yang telah disisipkan pesan) bahwa antara ukuran file coverimage dan ukuran file stego image tidak terdapat perubahan yang signifikan.

\subsubsection{Pengujian Recovery}

Pengujian terhadap recovey bertujuan untuk pesan yang disembunyikan harus dapat diungkapkan kembali, Karena tujuan steganografi adalah data hiding, maka sewaktu-waktu pesan rahasia didalam stego image harus dapat diambil kembali untuk digunakan lebih lanjut.

$$
\text { Akurasi }=\frac{\text { jumlah kata benar diekstraksi }}{\text { jumlah kata yang disisipkan }} \times 100 \%
$$

1. Presentase Baboon 100 stegofile $1=\frac{184}{184} \times 100 \%=100 \%$

2. Presentase Baboon500stegofile $1=\frac{184}{184} \times 100 \%=100 \%$

3. Presentase Baboon1000stegofile $1=\frac{184}{184} \times 100 \%=100 \%$

4. Presentase Lenna100stegofile $1=\frac{184}{184} \times 100 \%=100 \%$

5. Presentase Lenna500stegofile $1=\frac{184}{184} \times 100 \%=100 \%$

6. Presentase Lenna1000stegofile $1=\frac{184}{184} \times 100 \%=100 \%$

7. Presentase Pepper 100 stegofile $1=\frac{184}{184} \times 100 \%=100 \%$

8. Presentase Pepper 500stegofile $1=\frac{184}{184} \times 100 \%=100 \%$

9. Presentase Pepper 1000 stegofile $1=\frac{184}{184} \times 100 \%=100 \%$

10. Presentase Tiger 100 stegofile $1=\frac{184}{184} \times 100 \%=100 \%$

11. Presentase Tiger 500 stegofile $1=\frac{184}{184} \times 100 \%=100 \%$ 
12. Presentase Tiger 1000 stegofile $1=\frac{184}{184} \times 100 \%=100 \%$

13. Presentase Baboon 100 stegofile $2=\frac{476}{476} \times 100 \%=100 \%$

14. Presentase Baboon500stegofile $2=\frac{476}{476} \times 100 \%=100 \%$

15. Presentase Baboon 1000 stegofile $2=\frac{476}{476} \times 100 \%=100 \%$

16. Presentase Lenna100stegofile $2=\frac{476}{476} \times 100 \%=100 \%$

17. Presentase Lenna500stegofile $2=\frac{476}{476} \times 100 \%=100 \%$

18. Presentase Lenna 1000 stegofile $2=\frac{476}{476} \times 100 \%=100 \%$

19. Presentase Pepper 100 stegofile $2=\frac{476}{476} \times 100 \%=100 \%$

20. Presentase Pepper 500 stegofile $2=\frac{476}{476} \times 100 \%=100 \%$

21. Presentase Pepper 1000 stegofile $2=\frac{476}{476} \times 100 \%=100 \%$

22. Presentase Tiger 100 stegofile $2=\frac{476}{476} \times 100 \%=100 \%$

23. Presentase Tiger500stegofile $2=\frac{476}{476} \times 100 \%=100 \%$

24. Presentase Tiger 1000 stegofile $2=\frac{476}{476} \times 100 \%=100 \%$

Berdasarkan hasil pengujian akurasi dapat ditarik kesimpulan bahwa dari 24 citra yang diujikan tingkat keberhasilan aplikasi ini mampu mengektraksi pesan yang sama dengan pesan yang disisipkan dengan tingkat keberhasillanya adalah $100 \%$.

\subsubsection{Pengujian PSNR}

Setelah citra mengalami proses penyisipan, untuk mengetahui kualitas citra dilakukan perhitungan Peak Signal to Noise Ratio (PSNR). PSNR bertujuan untuk membandingkan kualitas citra sebelum dan sesudah disisipkan apakah terdapat perubahan (noise) yang signifikan pada pixel citra setelah dilakukan proses penyisipan bit-bit pesan. Untuk menentukan PSNR, terlebih dahulu ditentukan nilai rata-rata kuadrat error Mean Square Error (MSE) antara citra asli dan citra sesudah disisipkan (stego image) dengan menggunakan persamaan berikut:

1. Mean Square Error (MSE)

[4] MSE adalah nilai rata-rata kuadrat error antara citra asli (cover image) dengan citra hasil penyisipan (stego image). Perhitungan MSE menggunakan persamaan berikut:

$$
M S E=\frac{1}{M N} \sum_{i=0}^{m-1}=1 \sum_{j=0}^{n-1}=(I(i, j)-K(i, j))^{2}(3)
$$

Dimana:
MSE = Nilai Mean Square Error antara cover image dengan stego image
$\mathrm{m} \quad=$ panjang citra tersebut (dalam pixel)
$\mathrm{n} \quad=$ lebar citra tersebut (dalam pixel)
$(\mathrm{i}, \mathrm{j}) \quad=$ koordinat pixel
$\mathrm{I}=$ cover image
$\mathrm{K}=$ stego image

2. Peak to Signal Noise Ratio (PSNR)

PSNR sering dinyatakan dalam skala logaritmik, dalam decibel (dB). Menurut [7] nilai PSNR dibawah $30 \mathrm{~dB}$ mengindikasikan kualitas yang relatif rendah, dimana distorsi yang disebabkan penyisipan terlihat jelas. Sedangkan kualitas stego image yang tinggi berada pada 
nilai $40 \mathrm{~dB}$ dan diatasnya. Menurut [8] citra tidak mengalami perubahan kualitas yang signifikan dengan nilai PSNR diatas $30 \mathrm{~dB}$.

$$
P S N R=20_{\log } 10\left(\frac{255}{\sqrt{M S E}}\right)
$$

Berikut ini tabel hasil pengujian PSNR:

Tabel 4. Hasil Pengujian PSNR

\begin{tabular}{|c|c|c|c|}
\hline Output File & Ukuran File & Size File & $\begin{array}{l}\text { Nilai } \\
\text { PSNR }\end{array}$ \\
\hline Baboon100stegofile1.bmp & 30.054 byte & $3 \times(100 \times 100)$ Pixel & 51.12 \\
\hline Baboon500stegofile1.bmp & 750,054 byte & $3 \times(500 \times 500)$ Pixel & 51,12 \\
\hline Baboon1000stegofile1.bmp & $3,000,054$ byte & $\begin{array}{l}3 \times(1000 \quad x \quad 1000) \\
\text { Pixel }\end{array}$ & 51,13 \\
\hline Lenna100stegofile1.bmp & 30.054 byte & $3 \times(100 \times 100)$ Pixel & 51,17 \\
\hline Lenna500stegofile1.bmp & 750,054 byte & $3 \times(500 \times 500)$ Pixel & 51,20 \\
\hline Lenna1000stegofile1.bmp & $3,000,054$ byte & $\begin{array}{l}3 \times(1000 \quad x \quad 1000) \\
\text { Pixel }\end{array}$ & 51,20 \\
\hline Pepper100stegofile1.bmp & 30.054 byte & $3 \times(100 \times 100)$ Pixel & 51,18 \\
\hline Pepper500stegofile1.bmp & 750,054 byte & $3 \times(500 \times 500)$ Pixel & 51,16 \\
\hline Pepper1000stegofile1.bmp & $3,000,054$ byte & $\begin{array}{l}3 \times x \quad(1000 \quad x \quad 1000) \\
\text { Pixel }\end{array}$ & 51,10 \\
\hline Tiger100stegofile1.bmp & 30.054 byte & $3 \times(100 \times 100)$ Pixel & 51,15 \\
\hline Tiger500stegofile1.bmp & 750,054 byte & $3 \times(500 \times 500)$ Pixel & 51,15 \\
\hline Tiger1000stegofile1.bmp & $3,000,054$ byte & $\begin{array}{l}3 \times(1000 \quad x \quad 1000) \\
\text { Pixel }\end{array}$ & 51,04 \\
\hline Baboon100stegofile2.bmp & 30.054 byte & $3 \times(100 \times 100)$ Pixel & 51,12 \\
\hline Baboon500stegofile2.bmp & 750,054 byte & $3 \times(500 \times 500)$ Pixel & 51,13 \\
\hline Baboon1000stegofile2.bmp & $3,000,054$ byte & $\begin{array}{l}3 \times(1000 \quad x \quad 1000) \\
\text { Pixel }\end{array}$ & 51,19 \\
\hline Lenna100stegofile2.bmp & 30.054 byte & $3 \times(100 \times 100)$ Pixel & 51,14 \\
\hline Lenna500stegofile2.bmp & 750,054 byte & $3 \times(500 \times 500)$ Pixel & 51,16 \\
\hline Lenna1000stegofile2.bmp & $3,000,054$ byte & $\begin{array}{l}3 \quad x \quad(1000 \quad x \quad 1000) \\
\text { Pixel }\end{array}$ & 51,19 \\
\hline Pepper100stegofile2.bmp & 30.054 byte & $3 \times(100 \times 100)$ Pixel & 51,14 \\
\hline Pepper500stegofile2.bmp & 750,054 byte & $3 \times(500 \times 500)$ Pixel & 51,11 \\
\hline Pepper1000stegofile2.bmp & $3,000,054$ byte & 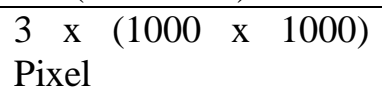 & 51,11 \\
\hline Tiger100stegofile2.bmp & 30.054 byte & $3 \times(100 \times 100)$ Pixel & 51,14 \\
\hline Tiger500stegofile2.bmp & 750,054 byte & $3 \times(500 \times 500)$ Pixel & 51,15 \\
\hline Tiger1000stegofile2.bmp & $3,000,054$ byte & $\begin{array}{l}3 \times(1000 \quad x \quad 1000) \\
\text { Pixel }\end{array}$ & 51,07 \\
\hline
\end{tabular}

Berdasarkan Tabel 4 hasil uji perbandingan penilaian kualitas citra digital yang dilakukan dengan cara menghitung nilai Peak Signal To Noise Rational (PSNR). Perbandingan, 24 stego image mendapatkan nilai PSNR yang tinggi berada diatas $51 \mathrm{~dB}$, disimpulkan bahwa citra berkualitas baik dan tidak mengalami perubahan kualitas citra yang signifikan, dikarenakan hanya mengubah bit terendah pada pixel. 


\section{KESIMPULAN}

Berdasarkan hasil penelitian tentang steganografi citra menggunakan metode Least Significant Bit (LSB) dan Linear Congruential Generator (LCG) untuk melakukan penyisipan pesan rahasia kedalam citra maka dapat ditarik kesimpulan:

1. Berhasil menerapkan metode Least Significant Bit (LSB) untuk penyisipan pesan teks dan metode Linear Congruential Generator (LCG) sebagai pengacakan indeks posisi pixel tempat disisipkannya pesan teks pada aplikasi steganografi.

2. Aplikasi steganografi ini membuktikan bahwa metode LSB dan LCG yang digunakan menghasilkan stego image dengan kualitas yang baik dan dapat dibuktikan dengan hasil pengujian nilai PSNR yang mencapai $51 \mathrm{~dB}$.

\section{SARAN}

Dengan melihat hasil yang dicapai pada penelitian ini ada beberapa hal yang penulis sarankan untuk pengembangan aplikasi selanjutnya yaitu:

1. Diharapkan untuk pengembangan selanjutnya dapat menggunakan media citra digital lainnya sebagai penampung dan dapat menyimpan pesan dengan berbagai macam format lainnya.

2. Diharapkan dapat dikembankan lebih lanjut agar stego image tetap tangguh menghadapi rotasi, resize, cropping dan manipulasi data lainnya.

\section{UCAPAN TERIMA KASIH}

Penulis mengucapkan terima kasih kepada kedua orang tuaku dan kedua dosen pembimbingku yang telah memberikan dukungan terhadap penelitian ini.

\section{DAFTAR PUSTAKA}

[1] S. Sembiring. 2013, "Perancangan Aplikasi Steganografi untuk Menyisipkan Pesan Teks pada Gambar Dengan Metode End of File," Pelita Informatik, Budi Darma, Vol. IV.

[2] R. Munir. 2006, Pengolahan Citra Digital, Informatika, Bandung.

[3] H. Nando Winata and R. Nasrul Fuad, 2017. "Konses Penyandian File JPEG Menggunakan Metode LSB, ” Jurnal Nasional Informatika dan Teknologi. Jaringan, Vol. 1, No. 2.

[4] E. R. Djuwitaningrum and M. Apriyani, 2016. "Teknik Steganografi Pesan Teks Menggunakan Metode Least Significant Bit dan Algoritma Linear Congruential Generator (Text Message Steganography Using Least Significant Bit Method and Linear Congruential Generator Algorithm )," Vol. IV, No. November, pp. 79-85.

[5] Rosa A.S dan M.Shalahuddin, 2015. Rekayasa Perangkat Lunak Terstruktur dan Berorientasi Objek, Informatika, Bandung.

[6] S. . Park and K. . Miller, 1988. "Random Number Generators: Goods One Are Hard To Find, Communication of The ACM," Vol. 31, No. 10, pp. 1192-1201. 
[7] A. Cheddad, J. Condell, K. Curran, and P. M. Kevvit, 2010. "Digital Image Steganography Survey and Analysis of Current Methods," Vol. 90.

[8] D. Sartika, "Pengembangan Perangkat Lunak Penyembunyian Pesan Terenkripsi Menggunakan Algoritma Mars pada Citra Digital Dengan Metode Adaptif," Jurnal Ilmiah Informatika Global, vol. 7, No. 1, pp. 1-6, 2016. 